\title{
Effect of photodynamic therapy using diode laser and a novel plant extract irrigant against Enterococcus faecalis and Candida albicans
}

\author{
Doaa M. Sadony ${ }^{1}$, Maram E. Khallaf ${ }^{{ }^{*}}$ (1) and Jackline Samir Kamal ${ }^{2}$
}

\begin{abstract}
Background: To evaluate the antibacterial effect of diode laser and photodynamic therapy using methylene blue dye when used alone or in combination with Moringa oleifera extract on root canal microbes. A total of 50 single root canals with single straight canals were prepared with ProTaper files, sterilized in an autoclave device, contaminated with root canal microbes (Enterococcus faecalis and Candidia albicans) and placed in incubator for 21 days. They were then randomly divided into 6 groups. Laser group: (10 root canals) were subjected to laser only. Moringa group: (10 root canals) were irrigated using plant extract only (Moringa). PDT group: (10 root canals) were irrigated using Moringa and Methylene blue then subjected to laser. Methylene blue and laser group: (10 root canals) were irrigated using methylene blue then subjected to laser. Negative control group: (10 root canals) weren't irrigated. After treatment microbial assessment (colony count) was done. Data was analyzed using ANOVAs test.
\end{abstract}

Results: Moringa/laser group and PDT group showed statistically least bacterial count for both E. faecalis and Candida albicans. Moringa only group showed statistically less bacterial count than control group.

Conclusion: The combined use of PDT together with Moringa oleifera has the best antimicrobial effect.

Keywords: Moringa oleifera, PDT, Diode laser, E. faecalis

\section{Background}

The main goal of root canal treatment is removal of the pulpal debris, microorganisms and bacterial byproducts from the root canal system. This aim is mainly done through chemomechanical preparation, however, studies have showed that half of the dentinal walls may remain untouched after mechanical preparation, as a result of the complex anatomy of the root canal systems (Del Carpio-Perochena et al. 2014; Delgado et al. 2010; Vianna et al. 2007). Enterococcus faecalis and Candida albicans are some of the most common microorganisms found in

\footnotetext{
*Correspondence: maram_3@yahoo.com

${ }^{1}$ Restorative and Dental Materials Department, National Research Centre, Cairo, Egypt

Full list of author information is available at the end of the article
}

endodontically infected root canals (Persoon et al. 2017; Sundqvist et al. 1985). E. faecalis is a Gram-positive, non-sporing, facultative anaerobe that is usually found in chronic periodontitis and root canal retreatment cases (Seneviratne et al. 2013; Karale et al. 2016). Also, 20\% of primary root canal cases are associated with C. albicans (Persoon et al. 2017; Karale et al. 2016).

Biofilm is a community of micro-organisms that are firmly attached to the surface and encased in a self-made extracellular polymeric substance (EPS, usually a polysaccharide) (Siqueira and Rôças 2008).

The use of antibacterial root canal irrigants is mandatory to achieve success of the endodontic treatment. Commonly used root canal irrigtants cause adverse effect on the physical properties of dentin and also bacterial resistance is increasing with these irrigants (Baik 
et al. 2008; Estrela et al. 1998). Thus, a continuous search for alternative protocols for enhancing disinfection is needed. This could be new chemomechanical techniques, or other approaches that could complement the effects of conventional disinfection, such as photodynamic therapy (PDT) and laser disinfection. Dental applications of PDT are increasing rapidly, studies have also shown that PDT is highly effective against oral bacteria (Bonsor et al. 2006; Soukos et al. 2006).

PDT has the advantage of having an immediate action, the ability to reach complex areas in the root canal system, it could also prevent bacteremia in immunocompromised patients (Asnaashari et al. 2016; Silva et al. 2012). Photosensitizer is capable of being selectively accumulated in tissues, allowing for the release of oxygen and free radicals. That's why, PDT specifically targets the microorganisms without causing any harm to host tissues. PDT is performed using light emitting diode (LED) or laser. It was proven that high power diode laser is capable of disinfecting the root canal system and has the ability to reach the complex anatomical structures, that other techniques could not reach (Bago et al. 2013). High power lasers disinfecting effect is related to the heat produced by selective dose (Asnaashari et al. 2016). Moringa oleifera is a native Indian tree that proved to have antiviral, antibacterial, antioxidant, antisclerotic and antiinflammatory properties (Jung 2014), and has been previously investigated as a root canal irrigant (Khallaf et al. 2020).

Literature is scarce regarding studies comparing PDT, laser and root canal irrigants on the biofilm of E. faecalis and $C$. albicans, so the aim of this research is to compare the effect of PDT, M. Oliefera and Diode laser on E. faecalis and C. albicans in the root canal system.

\section{Methods}

\section{Selection and preparation of the specimens}

Study protocol was reviewed and accepted by the ethical committee of the National Research Centre, acceptance no. 16/344. The study sample consisted of 50 extracted human single rooted teeth. Each tooth was stored in $0.5 \%$ chloramine-T solution at $4{ }^{\circ} \mathrm{C}$ after extraction and until the time of use. The external root surface was cleaned using periodontal curettes to remove periodontal soft tissue. Teeth with root caries or previous endodontic treatment were excluded. A periodical mesiodistal and buccolingual radiographs were made to ensure presence of a single root canal and to exclude any tooth with root cracks. The teeth were decoronated transversally at the cemento-enamel junction (CEJ) with a double-faced diamond disc (Microdont LDA, Brazil) at low speed with water coolant to ensure a uniform sample length of $15 \mathrm{~mm}$ ( $\pm 1 \mathrm{~mm}$ root length).
A \#10 K file was introduced into each canal until being visible at the apical foramen and working length was established by subtracting $1 \mathrm{~mm}$ from this length.

The canals were prepared up to size \#30 Protaper rotary file \#F3 (Maillefer/Dentsply, Switzerland), according to the manufacturer's instruction. After each file, the canals were irrigated with $2 \mathrm{ml}$ of $5.25 \%$ sodium hypochlorite $(\mathrm{NaOCl})$ using a 30 Gauge needle. At the end of the canal preparation, EDTA $17 \%, 5.25 \% \mathrm{NaOCl}$ and normal saline for $1 \mathrm{~min}$ were used respectively to ensure removal of the smear layer. The apical foramina were sealed with Glass Ionomer (Fuji II LC/GC, Japan), and a nail varnish was applied on the external root surface to prevent communication with the external surface. All of the specimens were sterilized in autoclave under $15 \mathrm{psi}$ pressure at $121^{\circ} \mathrm{C}$ for $30 \mathrm{~min}$.

\section{Preparation of inoculation and contamination of root canals with E. faecalis and C. albicans E. faecalis inoculation}

Twenty five samples were randomly selected. A suspension was prepared by mixing a pure culture of E. faecalis (ATCC 19433) in sterile saline at a concentration of $1.5 \times 108 \mathrm{CFU} / \mathrm{ml}$ which was used for inoculation. The bacterial suspension was adjusted spectro-photometrically to match the turbidity of a McFarland 0.5 scale. A $0.01 \mathrm{ml}$ aliquot of the suspension was inoculated into each canal using a sterile insulin syringe. Then the samples were incubated for three weeks under aerobic conditions at $37^{\circ} \mathrm{C}$.

\section{C. albicans inoculation}

Twenty five prepared samples were used. A suspension was prepared by mixing a pure culture of C. albicans (ATCC 10231) in sterile saline at a concentration of $1.5 \times 108 \mathrm{CFU} / \mathrm{ml}$ which was used for inoculation. The fungal suspension was adjusted spectro-photommetrically to match the turbidity of a McFarland 0.5 scale. A $0.01 \mathrm{ml}$ aliquot of the suspension was inoculated into each canal using a sterile insulin syringe. Then the samples were incubated for three weeks under aerobic conditions at $37^{\circ} \mathrm{C}$.

After the incubation period the root canal samples were divided into 5 groups:

Laser group: (10 root canals) were subjected to laser only (5 from $E$. faecalis group and 5 from C. albicans one).

Moringa group: (10 root canals) were irrigated using plant extract only (Moringa) (5 from E. faecalis group and 5 from $C$. albicans one).

PDT group: (10 root canals) were irrigated using Moringa followed by Methylene blue then subjected 
to laser (5 from E. faecalis group and 5 from C. albicans one).

Moringa and laser group: (10 root canals) were irrigated using methylene blue then subjected to laser (5 from E. faecalis group and 5 from C. albicans one).

Negative control group: (10 root canals) weren't irrigated (5 from $E$. faecalis group and 5 from C. albicans one).

A total volume of $3 \mathrm{ml}$ of irrigants was used for the disinfection of root canal of each sample in all experimental groups while irrigating for a total of $3 \mathrm{~min}$.

A flask containing $300 \mathrm{ml}$ of melted blood agar medium was prepared where the agar medium was pre-sterilized in an autoclave on the same day it was needed for the experiment.

Root canals were sampled and cultured before and after the use of each irrigant, a smooth broach was inserted into the root canal and agitated for $1 \mathrm{~min}$ (Estrela et al. 1998), and then a paper point size 40 was inserted into the root canal for $60 \mathrm{~s}$ to complete bacterial and fungal sampling till the working length. After tenfold serial dilutions, aliquots of $0.1 \mathrm{ml}$ were plated onto blood agar plates and incubated at $37{ }^{\circ} \mathrm{C}$ for $24 \mathrm{~h}$. The CFU were counted and recorded to determine the number of colony-forming units (CFUs) per plate before and after irrigation.

All procedures were carried out in a laminar flow chamber (SAFZONE).

For PDT, a methylene blue dye (SDFCL Industries, Mumbai, India) was prepared by dissolution in distilled water and was filter-sterilized immediately before use. The final concentration used was $25 \mu \mathrm{g} / \mathrm{ml}$. The dye was then injected into the canals of each sample. The irradiation source was a diode laser (A gallium-aluminum-arsenide (GaAlAS) diode laser Siro-Laser Advance class IIIb SIRONA the Dental Company,Germany) with an output power of $1.5 \mathrm{~W}$ and a wavelength of $970 \mathrm{~nm}$. A $200 \mu \mathrm{m}$ diameter optical fiber was used. The laser handpiece was held at an angle of $10^{\circ}$ between the fiber and root canal wall. Laser irradiation was performed three times for $5 \mathrm{~s}$ each with an interval of $10 \mathrm{~s}$ between irradiations on continuous mode. The laser irradiation was delivered into the canal up to $1 \mathrm{~mm}$ short of the working length while moving coronally without any water spray or air cooling.

\section{Statistical analysis}

The mean and standard deviation values were calculated for each group in each test. Viable counts of antibacterial activity were transformed to their $\log 10$ values. Data were explored for normality using Kolmogorov-Smirnov and Shapiro-Wilk tests and showed parametric (normal) distribution.

One-way ANOVA followed by Tukey post hoc test was used to compare between more than two groups in nonrelated samples.

The significance level was set at $p \leq 0.05$. Statistical analysis was performed with IBM ${ }^{\circledR}$ SPSS $^{\circledR}$ Statistics Version 20 for Windows.

\section{Results}

\section{Candida albicans results}

Control group had a statistically significant higher CFU than both (Moringa and Laser) and (PDT) groups where $(p=0.002)$ and $(p=0.009)$ respectively.

No statistically significant difference was found between any other pair.

\section{E. faecalis results}

Control group also showed the statistically significant highest CFU than (Moringa), (Moringa and Laser), (PDT) and (Laser) groups where $(p<0.001)$.

Also, a statistically significant difference was found between (Moringa) and each of (Moringa and Laser), (PDT) and (Laser) groups where $(p<0.001)$. (Table 1$)$.

\section{Discussion}

The key to a successful endodontic treatment is complete removal of root canal microorganisms. The use of current antimicrobial root canal irrigants alone is not adequate to completely eradicate microorganisms from the root canal systems, thus there is a continuous search for more effective disinfection protocols (Asnaashari et al. 2017).

C. albicans and E. faecalis have been found in most of the infected root canal systems and mostly found in secondary and persistent infections. Also E.faecalis is known

Table 1 The mean, standard deviation (SD) values of LOG 10 of C. albicans and E. faecalis bacterial count of different groups

\begin{tabular}{llllll}
\hline Variables & \multicolumn{4}{l}{ Candida and bacterial count } \\
\cline { 2 - 3 } & \multicolumn{2}{l}{ Candida } & & \multicolumn{2}{l}{ E. faecalis } \\
\cline { 2 - 3 } \cline { 5 - 6 } & Mean & SD & & Mean & SD \\
\hline Control & $4.46^{\mathrm{a}}$ & 0.19 & $6.20^{\mathrm{a}}$ & 0.06 \\
Moringa & $3.12^{\mathrm{ab}}$ & 0.16 & $4.78^{\mathrm{b}}$ & 0.05 \\
Moringa and laser & $1.32^{\mathrm{b}}$ & 1.81 & & $4.15^{\mathrm{c}}$ & 0.16 \\
PDT & $1.80^{\mathrm{b}}$ & 1.64 & & $4.25^{\mathrm{c}}$ & 0.05 \\
Laser & $3.12^{\mathrm{ab}}$ & 0.16 & $4.30^{\mathrm{c}}$ & 0.08 \\
$p$ value & $0.002^{*}$ & & $<0.001^{*}$ & \\
\hline
\end{tabular}

Means with different letters in the same column indicate statistically significance difference

* significant $(p<0.05)$ 
to form calcified monoculture biofilms at 3 weeks and can be easily cultivated in vitro. Bacteria in a biofilm are more resistant to antimicrobial agents than in a planktonic case. Hence, this study used a bacterial biofilm to resemble the more difficult clinical situation (Kishen et al. 2008; Mohammadi and Abbott 2009; Delgado et al. 2010; Sato et al. 1996; Guerreiro-Tanomaru et al. 2013; Rodrigues et al. 2018).

Photodynamic therapy (PDT) is a technique that could improve endodontic disinfetion protocols and it does not require more than one visit. PDT requires three factors: Photosensitizer, light source and tissue oxygen (Svensater and Bergenholtz 2004).

PDT works in the presence of free oxygen radicals. PDT action can destruct the microorganisms together with the cellular molecules, such as proteins, membrane lipids, nucleus and nucleic acids. The choice of the size of the fiber optic is mandatory for the success of PDT as it greatly affects the depth of penetration. PDT also has the advantage of removing both periodontal and endodontic microorganism with almost no side effects (Moor et al. 2010).

Diode laser with a wide range of wavelengths have been used for PDT. To our knowledge limited literature is available on the effect of diode laser $970 \mathrm{~nm}$ on root canal disinfection. Hence, in the present study, a high-power diode laser of $970 \mathrm{~nm}$ was used as the light source, and methylene blue dye $25 \mu \mathrm{g} / \mathrm{ml}$ was utilized as the photosensitizer (Soukos et al. 2006; Gutknecht et al. 2004).

For standardization purposes, the total volume of irrigants and the time of irrigation were kept constant throughout the study for all the experimental groups. A total volume of $3 \mathrm{ml}$ of irrigants was used for the disinfection of root canal of each sample in all experimental groups while irrigating for a total of $3 \mathrm{~min}$.

The bactericidal effect of laser is mainly related to the type of laser and the heat produced inside the root canal. However, improper selection of the parameters might cause complications such as, root resorption, cementum damage and apical necrosis (Asnaashari et al. 2016). When comparing the bactericidal effect of PDT and laser alone, several studies have found that the antibacterial effect of PDT is higher than laser (Afkhami et al. 2017).

Previous studies have showed the antibacterial effect of Moringa oleifera leaf extract which has been attributed to its content of saponins, flavonoids, tannins, alkaloids, phenolics, and triterpenoids (Wang et al. 2016).

The antibacterial effect of saponins is attributed to its interference with the permeability of the bacterial cell wall (Podolak et al. 2010; Arabski et al. 2012). While flavonoid compounds form complex compounds with proteins so that the tertiary structure of the protein is disrupted, causing denaturation of proteins and nucleic acids. This denaturation causes protein coagulation and interferes with the metabolism and physiological functions of bacteria (Xie et al. 2015).

Flavonoids also inhibit cell membrane synthesis and aggregate effects on all bacterial cells (Cushnie and Lamb 2005).

Tannin compounds can inhibit protein synthesis for cell wall formation and shrink cell walls, thereby disrupting cell permeability and leading to cell death (Length 2006; Akiyama et al. 2001). Alkaloids antibacterial effect is due to its interference with the components of peptidoglycan in bacterial cells leading to disruption of the formation of intact cell wall layers, thus causing cell death (Cushnie et al. 2014). Terpenoid compounds causes damage to the outer cell membrane, leading to the entry of compounds that reduce the permeability of the bacterial cell wall thus the bacterial cell lacks nutrients and bacterial growth is inhibited (Cowan 1999).

In our study, groups with laser showed least bacterial count for both E. faecalis and C. albicans, and groups with both laser and $M$. oliefera showed the statistically significant least bacterial count. However no significant difference was found between PDT group and M. oliefera and laser group.

PDT group did not show lower bacterial count than $M$. oliefera and laser only group this is in contrary to several studies, but the difference can be attributed to the use of $M$. oliefera in this study which could enhance the antibacterial effect of laser group.

\section{Conclusion}

The use of Moringa oliefera enhances the antibacterial effect of the laser assisted cleansing.

The combined use of Laser and Moringa oliefera is as effective as PDT and is considered to be better than Moringa Oliefera irrigant alone or even laser alone.

\section{Abbreviations}

PDT: Photodynamic therapy; E. faecalis: Enterococcus faecalis; C. albicans: Candida albicans; EPS: Extracellular polymeric substance; M. oliefera: Moringa oliefera; LED: Light emitting diode; CEJ: Cementoenamel junction; MB: Methylene blue.

\section{Acknowledgements}

Not applicable.

\section{Authors' contributions}

DS, applied the disinfection protocol as well as writing the manuscript, ME prepared the root canals and wrote the manuscript, JK, inoculated the root canal and analyzed the amount of microorganism growth. All authors have read and approved the manuscript.

Funding

Not applicable.

Availability of data and materials

Not applicable. 


\section{Ethics approval and consent to participate}

Study protocol was reviewed and accepted by the ethical committee of the National Research Centre, acceptance no. 16/344.

\section{Consent for publication}

Not applicable.

\section{Competing interests}

There are no conflicts of interest.

\section{Author details}

${ }^{1}$ Restorative and Dental Materials Department, National Research Centre, Cairo, Egypt. ${ }^{2}$ Clinical and Chemical Pathology Department, National Research Centre, Cairo, Egypt.

Received: 14 January 2021 Accepted: 24 February 2021 Published online: 04 March 2021

\section{References}

Afkhami F, Akbari S, Chiniforush N (2017) Entrococcus faecalis elimination in root canals using silver nanoparticles, photodynamic therapy, diode laser, or laser-activated nanoparticles: an in vitro study. J Endod 43:279-282

Akiyama H, Fujii K, Yamasaki O, Oono T, Iwatsuki K (2001) Antibacterial action of several tannins against Staphylococcus aureus. J Antimicrob Chemother 48:487-491

Arabski M, Węgierek-Ciuk A, Czerwonka G, Lankoff A, Kaca W (2012) Effects of saponins against clinical E. coli strains and eukaryotic cell line. J Biomed Biotechnol 2012:286216

Asnaashari M, Mojahedi SM, Asadi Z, Azari-Marhabi S, Maleki A (2016) A comparison of the antibacterial activity of the two methods of photodynamic therapy (using diode laser $810 \mathrm{~nm}$ and LED lamp $630 \mathrm{~nm}$ ) against Enterococcus faecalis in ex-tracted human anterior teeth. Photodiagnosis Photodyn Ther 13:233-237

Asnaashari M, Mojahedi SM, Asadi Z, Azari-Marhabi S, Maleki A (2016) A comparison of the antibacterial activity of the two methods of photodynamic therapy (using diode laser $810 \mathrm{~nm}$ and LED lamp $630 \mathrm{~nm}$ ) against Enterococcus faecalis in extracted human anterior teeth. Photodiagnosis Photodyn Ther 13:233-237

Asnaashari MAH, Rahmati A, Amini N (2017) A comparison between effect of photo- dynamic therapy by LED and calcium hydroxide therapy for root canal disinfection against Enterococcus faecalis: a randomized controlled trial. Photodiagnosis Photodyn Ther 17:226-232

Bago I, Plecko V, Gabric Panduric D, Schauperl Z, Baraba A, Anic I (2013) Antimicrobial efficacy of a high-power diode laser, photo-activated disinfection, conventional and sonic activated irrigation during root canal treatment. Int Endod J 46:339-347

Baik JE, Kum KY, Yun CH, Lee JK, Lee K, Kim KK et al (2008) Calcium hydroxide inactivates lipoteichoic acid from Enterococcus faecalis. J Endod 34:1355-1359

Bonsor SJ, Nichol R, Reid TM, Pearson GJ (2006) Micro- biological evaluation of photo-activated disinfection in endodontics (an in vivo study). Br Dent J 25:337-341

Cowan MM (1999) Plant products as antimicrobial agents. Clin Microbiol Rev 12:564-582

Cushnie TP, Lamb AJ (2005) Antimicrobial activity of flavonoids. Int J Antimicrob Agents 26:343-356

Cushnie TP, Cushnie B, Lamb AJ (2014) Alkaloids: an overview of their antibacterial, antibiotic-enhancing and antivirulence activities. Int J Antimicrob Agents 44:377-386

De Moor RJG, Meire M, Goharkhay K, Moritz A, Vanobbergen J (2010) Efficacy of ultrasonic versus laser-activated irrigation to remove artificially placed dentin debris plugs. J Endod 36:1580-1583

Del Carpio-Perochena A, Bramante CM, Hungaro Duarte MA, de Andrade FB, Cavenago BC, Villas-Boas MH et al (2014) Application of laser scanning microscopy for the analysis of oral biofilm dissolution by different endodontic irrigants. Dent Res J 11:442-447

Delgado RJ, Gasparoto TH, Sipert CR, Pinheiro CR, Moraes IG, Garcia RB et al (2010) Antimicrobial effects of calcium hydroxide and chlorhexidine on Enterococcus faecalis. J Endod 36:1389-1393
Estrela C, Pimenta FC, Ito IY, Bammann LL (1998) In vitro determination of direct antimicrobial effect of calcium hydroxide. J Endod 24:15-17

Guerreiro-Tanomaru JM, de Faria-Junior NB, Duarte MA, Ordinola-Zapata R, Graeff MS, Tanomaru-Filho M (2013) Comparative analysis of Enterococcus faecalis biofilm formation on different substrates. J Endod 39:346-350

Gutknecht N, Franzen R, Schippers M, Lampert F (2004) Bactericidal effect of a $980-n m$ diode laser in the root canal wall dentin of bovine teeth. J Clin Laser Med Surg 22:9-13

Jung $L$ (2014) Soluble extract from Moringa oleifera leaves with a new anticancer activity. PLoS ONE 9(4):e95492

Karale R, Odedra KM, Srirekha A, Champa C, Shetty A, Pushpalatha S et al (2016) Effect of dentin on the antimicrobial efficacy of 3\% sodium hypochlorite, $2 \%$ chlorhexidine, $17 \%$ ethylenediaminetetraacetic acid, and $18 \%$ etidronic acid on Candida albicans: an in vitro study. J Conserv Dent 19:455-460

Khallaf ME, Kataia EM, Aly Y et al (2020) Cleanliness efficacy and effect on dentin microhardness of a novel plant extract irrigant. Bull Natl Res Cent $44: 47$

Kishen A, Shi Z, Shrestha A, Neoh KG (2008) An investigation on the antibacterial and antibiofilm efficacy of cationic nanoparticulates for root canal disinfection. J Endod 34:1515-1520

Length $F(2006)$ In vitro evaluation of the interaction between tea extracts and penicillin G against Staphylococcus aureus. Afr J Biotechnol 5:1082-1086

Mohammadi Z, Abbott PV (2009) The properties and applications of chlorhexidine in endodontics. Int Endod J 42:288-302

Persoon IF, Crielaard W, Ozok AR (2017) Prevalence and nature of fungi in root canal infections: a systematic review and meta-analysis. Int Endod J 50:1055-1066

Podolak I, Galanty A, Sobolewska D (2010) Saponins as cytotoxic agents: a review. Phytochem Rev 9:425-474

Rodrigues CT, de Andrade FB, de Vasconcelos LR et al (2018) Antibacterial properties of silver nanoparticles as a root canal irrigant against Enterococcus faecalis biofilm and infected dentinal tubules. Int Endod J 51(8):901-911

Sato I, Ando-Kurihara N, Kota K, Iwaku M, Hoshino E (1996) Sterilization of infected root-canal dentine by topical application of a mixture of ciprofloxacin, me-tronidazole and minocycline in situ. Int Endod J 29:118-124

Seneviratne CJ, Yip JW, Chang JW, Zhang CF, Samaranayake LP (2013) Effect of culture media and nutrients on biofilm growth kinetics of laboratory and clinical strains of Enterococcus faecalis. Arch Oral Biol 58:1327-1334

Silva LA, Novaes AB Jr, de Oliveira RR, Nelson-Filho P, Santamaria M Jr, Silva RA (2012) Antimicrobial photodynamic therapy for the treatment of teeth with apical periodontitis: a histopathological evaluation. J Endod 38:360-366

Siqueira JF Jr, Rôças IN (2008) Clinical implications and microbiology of bacterial persistence after treatment procedures. J Endod 34:1291-1301

Soukos NS, Chen PS, Morris JT, Ruggiero K, Abernethy AD, Som S et al (2006) Photodynamic therapy for endodontic disinfection. J Endod 32:979-984

Sundqvist G, Figdor D, Persson S, Sjogren U (1985) Microbiologic analysis of teeth with failed endodontic treatment and the outcome of conservative re-treatment. Oral Surg. Oral Med. Oral Pathol Oral Radiol Endod 85:86-93

Svensater G, Bergenholtz G (2004) Biofilms in endodontic infections. Endod Top 9:27-36

Vianna ME, Horz HP, Conrads G, Zaia AA, Souza-Filho FJ, Gomes BP (2007) Effect of root canal procedures on endotoxins and endodontic pathogens. Oral Microbiol Immunol 22:411-418

Wang L, Chen X, Wu A (2016) Mini review on antimicrobial activity and bioactive compounds of Moringa oleifera. Med Chem (Los Angeles) 6:578-582

Xie Y, Yang W, Tang F, Chen X, Ren L (2015) Antibacterial activities of flavonoids: structure-activity relationship and mechanism. Curr Med Chem 22:132-149

\section{Publisher's Note}

Springer Nature remains neutral with regard to jurisdictional claims in published maps and institutional affiliations. 